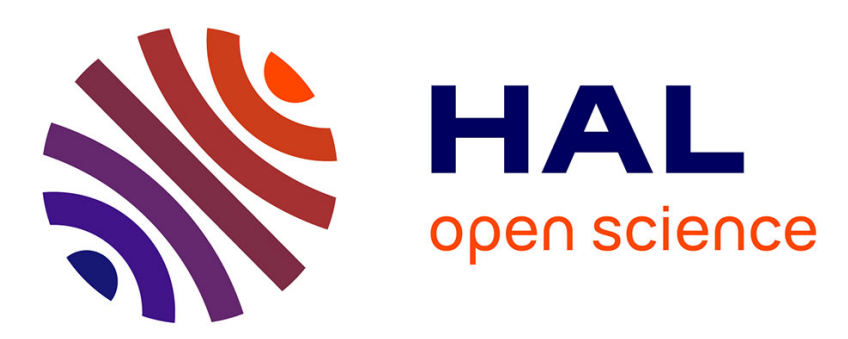

\title{
Lanthanide containing ionic liquid crystals: EuBr2, SmBr3, TbBr3 and DyBr3 in C12mimBr
}

\author{
Anja-Verena Mudring
}

\section{To cite this version:}

Anja-Verena Mudring. Lanthanide containing ionic liquid crystals: EuBr2, SmBr3, TbBr3 and DyBr3 in C12mimBr. Journal of Inorganic and General Chemistry / Zeitschrift für anorganische und allgemeine Chemie, 2010, 636 (9-10), pp.1726. 10.1002/zaac.201000070 . hal-00552457

\section{HAL Id: hal-00552457 \\ https://hal.science/hal-00552457}

Submitted on 6 Jan 2011

HAL is a multi-disciplinary open access archive for the deposit and dissemination of scientific research documents, whether they are published or not. The documents may come from teaching and research institutions in France or abroad, or from public or private research centers.
L'archive ouverte pluridisciplinaire HAL, est destinée au dépôt et à la diffusion de documents scientifiques de niveau recherche, publiés ou non, émanant des établissements d'enseignement et de recherche français ou étrangers, des laboratoires publics ou privés. 


\section{Lanthanide containing ionic liquid crystals: EuBr2, SmBr3, TbBr3 and DyBr3 in C12mimBr}

\begin{tabular}{|c|c|}
\hline Journal: & Zeitschrift für Anorganische und Allgemeine Chemie \\
\hline Manuscript ID: & zaac. $201000070 . R 1$ \\
\hline Wiley - Manuscript type: & Article \\
\hline $\begin{array}{l}\text { Date Submitted by the } \\
\text { Author: }\end{array}$ & 14-Mar-2010 \\
\hline Complete List of Authors: & $\begin{array}{l}\text { Mudring, Anja-Verena; Ruhr-Universitaet Bochum, Anorganische } \\
\text { Chemie I }\end{array}$ \\
\hline Keywords: & Ionic Liquids, Liquid Crystals, Luminescence, Lanthanides \\
\hline
\end{tabular}

\section{\scholaroNE" \\ Manuscript Central}




\title{
Lanthanide containing ionic liquid crystals: $\mathrm{EuBr}_{2}, \mathrm{SmBr}_{3}, \mathrm{TbBr}_{3}$ and $\mathrm{DyBr}_{3}$ in $\mathrm{C}_{12} \mathrm{mimBr}$
}

\author{
Anna Getsis and Anja-Verena Mudring* \\ Bochum, Fakultät für Chemie und Biochemie, Anorganische Chemie I, Festkörperchemie und Materialien, \\ Ruhr-Universität Bochum
}

Received

Dedicated to Professor Bernd Harbrecht on the Occasion of his $60^{\text {th }}$ Birthday.

\begin{abstract}
Doping the ionic liquid crystal $\mathrm{C}_{12} \mathrm{mimBr}$ with various lanthanide halides yields interesting novel liquid crystalline and luminescent materials. The thermal phase behavior of all compounds was investigated by hot-stage polarizing optical microscopy and differential scanning calorimetry and the photophysical properties were determined by luminescence spectroscopy. $\quad \mathrm{C}_{12} \mathrm{mimBr}$ itself is an ionic liquid crystal that shows bluish-white emission upon excitation with UV light due to transitions in the imidazolium $\pi$-system. Doping lanthanide bromides into $\mathrm{C}_{12} \mathrm{mimBr}$ with concentrations of about $1 \mathrm{~mol} \%$ does not affect the liquid crystalline behaviour of the host materials to a great extent and room temperature liquid crystals are obtained. All
\end{abstract}

\section{Introduction}

Although ionic liquids (ILs) have received an exceptionally high attention as a new class of solvents and materials for various applications, the understanding of interactions within these liquids is still rather limited. It has been noted from early on that ILs are highly structured liquids ${ }^{1}$. Ionic liquid crystals (ILCs) represent a special class of ILs where weak hydrophobic interactions of alkyl groups, dipole-dipole, cation- $\pi$ interactions as well as $\pi-\pi$ stacking of the commonly used aromatic head groups of the cation such as imidazolium or pyridinium as well as ionic interactions are tremendously important and are the driving force for the formation of ordered liquids, hence, liquid crystalline phases.

The liquid crystalline state of matter shows characteristics which are intermediate between that of a three-dimensionally well ordered crystalline solid and an isotropic liquid where the constituents are distributed randomly through space. ${ }^{2}$

\section{*Prof. Dr. Anja-Verena Mudring}

Ruhr-Universität Bochum, Fakultät für Chemie und Biochemie; Anorganische Chemie I - Festkörperchemie und Materialien

D-44780 Bochum

www.anjamudring.de materials show an appreciable luminescence. $\mathrm{EuBr}_{2}$ in $\mathrm{C}_{12} \mathrm{mimBr}$ yields a material which shows a blue emission originating from $4 f$ $5 d$-transitions. $\mathrm{SmBr}_{3}$-doped samples show a red and $\mathrm{TbBr}_{3}$ samples a green luminescence. Upon doping $\mathrm{C}_{12} \mathrm{mimBr}$ with $\mathrm{DyBr}_{3}$ an orange luminescent liquid crystalline material is obtained. Most interestingly the emission color for the $\mathrm{TbBr}_{3}$ and $\mathrm{DyBr}_{3}$ containing materials can be tuned from bluish-white (mainly $\mathrm{C}_{12} \mathrm{mimBr}$ emission) to green (for $\mathrm{TbBr}_{3}$ ) and orange-yellow (for $\mathrm{DyBr}_{3}$ ) depending on the wavelength of the excitation light used.

Keywords: Dysprosium; Europium; Ionic Liquid; Liquid Crystal; Luminescence; Samarium; Terbium

Generally, in the liquid crystalline state a random distribution of particles - like in a classical liquid - is observed at least in one direction of space whereas in another direction a substantially higher degree of order is observed which comes close to the periodicity of crystalline materials. Typically, many of the physicochemical properties of liquid crystals (LCs) such as refractive index, electric permittivity, magnetic susceptibility, and mechanical properties like viscosities are highly depent on the direction in which these properties are measured. This has shown to be useful for a wide variety of applications and, in consequence, molecular liquid crystalline materials have found widespread applications in display technology in laptops, mobile phones, or flat screen television sets. ${ }^{3}$

Whilst most known liquid crystals are neutral molecular organic compounds of strong anisotropic shape, ionic liquid crystals (ILCs) are constituted of anions and cations. Mesophasic behaviour can be introduced into such an ionic material via either one of the ions. It is known that 1-alkyl-3methylimidazolium salts with twelve and more carbon atoms in the side chain adopt mesophases and that the mesophase stability rapidly increases with increase in the alkyl chain length ${ }^{4}$. Most times, a lamellar mesophase, a smectic A phase or other highly ordered smectic phases are observed. It has been realized that ILCs show unique characteristics that cannot be observed in conventional molecular LCs. In ILCs a 
tetragonal smectic phase $\mathrm{S}_{\mathrm{T}}$ was observed for the first time. ${ }^{5}$ Recently, it was shown that double alkyl substituted imidazolium ILCs show strong non-Newtonian fluidic behavior in the LC state while they are Newtonian liquids in the liquid IL state. ${ }^{6}$ ILCs also show a strong tendency for spontaneous homeotropic alignment. ${ }^{7}$ Applications of ionic liquid crystals are, so far, as ion-conductive materials, organized reaction media or self-assembled nanostructured materials. $^{8}$

Metal-containing liquid crystals (metallomesogens) form a special class of ILCs. By choosing a suitable metal ion as the ILC constituent additional functionalities that origin from the metals such as redoxactivity, magnetism or luminescence can be introduced into the material. In consequence, multifunctional materials are obtained. Several reviews survey the intensive studies on neutral, uncharged metallomesogens. ${ }^{9}$ In contrast studies of ionic metallomesogens have been neglected until recently ${ }^{10,11}$. Metal based ionic liquid crystals are known for various transition metals. The majority of the metal-containing ionic liquids have the $\left[\mathrm{MX}_{4}\right]^{2-}$ structural building block with $\mathrm{M}=$ $\mathrm{Co}, \mathrm{Ni}, \mathrm{Cu}, \mathrm{Zn}, \mathrm{Pd}, \mathrm{Cd}$ and $\mathrm{X}=\mathrm{Cl}, \mathrm{Br}$ and sometimes $\mathrm{I}$. Typical counter cations are long-chain quaternary ammonium cations, ${ }^{12,13,14,15} \mathrm{~N}$-alkylpyrrolidinium, ${ }^{16} \mathrm{~N}$-alkylpyridinium cations, ${ }^{17}, 18,19,20,21,22$ and 1-alkyl-3-methylimidazolium cations $^{23}$ Lanthanide based ILCs such as $\left[\mathrm{C}_{12} \mathrm{mpyr}\right]_{3}\left[\mathrm{TbBr}_{3}\right]$ $\left(\mathrm{C}_{12} \mathrm{mpyr}=\mathrm{N}\right.$-dodecyl-N-methylimidazolium $)$, $\left[\mathrm{C}_{12} \mathrm{mim}\right]_{3} \mathrm{LnBr}_{6}\left(\mathrm{C}_{12} \mathrm{mim}=1\right.$-dodecyl-3-methylimidazolium; $\mathrm{Ln}=\mathrm{Dy}, \mathrm{Tb})^{25}$ or $\left[\mathrm{C}_{12} \mathrm{mim}_{4}\left[\mathrm{EuBr}_{6}\right] \mathrm{Br}^{26}\right.$

Special interest in the field of such metal-containing liquid crystals focuses on light emitting liquid crystals for potential applications in emissive LC displays. ${ }^{27}$ By incorporating 4f-element cations such as $\mathrm{Eu}^{2+}$ or $\mathrm{Tm}^{3+}$ for blue, $\mathrm{Eu}^{3+}$ or $\mathrm{Sm}^{3+}$ for red and $\mathrm{Tb}^{3+}$ for green emission LCs emitting in the three basic colors can be obtained. ${ }^{28}$ In addition, aligned luminescent LCs can emit polarized light. ${ }^{29}$ A high magnetic anisotropy of the lanthanide ion as found for $\mathrm{Tb}^{3+}, \mathrm{Dy}^{3+}$ and $\mathrm{Tm}^{3+}$ makes the alignment of the mesophase in an external magnetic field possible. ${ }^{30}$ Thus, such compounds might be of interest for the use of electric and magnetic switchable devices. ${ }^{31}$ However, aside from lanthanide-based ILCs another viable way to ionic liquid crystalline material which shows lanthanide emission is to dope ILCs with suitable lanthanide salts.

Here we report on $\mathrm{C}_{12} \mathrm{mimBr}$, a well known ionic liquid crystal ${ }^{32}$, doped with $\mathrm{EuBr}_{2}, \mathrm{SmBr}_{3}, \mathrm{TbBr}_{3}$ and $\mathrm{DyBr}_{3}$, which allows to obtain ILC materials which show luminescence in the three basic colors. The luminescence properties of the obtained hybrid materials are investigated by luminescence spectroscopy. The thermal behaviour and mesophase formation is investigated by combined thermal (differential scanning calorimetry, DSC) and temperature dependent polarized optical microscopy (POM).

\section{Experimental details.}

Handling of $\mathrm{C}_{12}$ mimBr and $\mathrm{EuBr}_{2}$ as well as $\mathrm{LnBr}_{3}$ ( $\mathrm{Ln} \mathrm{Pr}$, $\mathrm{Sm}, \mathrm{Tb}, \mathrm{Dy}$ ) containing samples was carried out under strict inert conditions (vacuum, argon) using advanced Schlenk and glove-box techniques.
1-Dodecyl-3-methylimidazolium bromide, $\mathbf{C}_{\mathbf{1 2}} \mathbf{m i m B r}$. For $\mathrm{C}_{12} \mathrm{mimBr} \quad 0.1 \mathrm{~mol}$ methylimidazole (99 \%, ABCR GmbH\&Co, Karlsruhe, D) is dissolved in $70 \mathrm{ml}$ dry acetonitrile. Then $0.1 \mathrm{~mol} \mathrm{n}$-dodecylbromide (99\% Acros organics, Geel, B) is added drop-wise and the reaction mixture is heated under reflux for $18 \mathrm{~h}$. After cooling to room temperature most of the solvent is removed under vacuum. Upon adding the concentrated acetonitrile solution to $300 \mathrm{ml}$ cold $\left(-30^{\circ} \mathrm{C}\right)$ and dry toluene, 1-dodecyl-3methylimidazolium bromide precipitates as a white powder. The reaction product is filtered off and re-crystallized two times from dry acetonitrile/toluene. The product is dried from any remaining solvent for $48 \mathrm{~h}$ under dynamic vacuum. Yield: $\sim 70 \%$.

$\underline{\delta}_{\mathrm{H}}\left(298 \mathrm{~K}, 300 \mathrm{MHz}, \mathrm{DMSO}-\mathrm{d}_{6}\right): 0.868$ [t, 3H, H-1]; 1.234 [br. S., 18H, H-2]; 1.766 [quint., 2H, H-3]; 3.848 [s, 3H, H5]; 4.149 [t, 2H, H-4]; 7.708 [m,1H, H-6]; 7.777 [m, 1H, H7]; 9.151 [br. S., 1H, H-8].

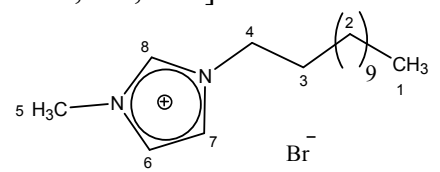

Scheme 1. Atom assignment in $\left[\mathrm{C}_{12} \mathrm{mim}\right] \mathrm{Br}(\mathbf{1})$.

MIR (KBr pellet): $\quad /\left[\mathrm{cm}^{-1}\right]=3226.5(\mathrm{w}), 3149.4(\mathrm{~m})$, 3083.8 (s), 3062.6 (s), 2950.7 (s), 2916.0 (s), 2869.7 (s), 2852.4 (s), $1772.4(\mathrm{w}), 1668.2(\mathrm{w}), 1629.7(\mathrm{~m}), 1571.8(\mathrm{~m})$, $1473.4(\mathrm{~m}), 1427.2(\mathrm{w}), 1384.7(\mathrm{w}), 1344.2(\mathrm{w}), 1317.2(\mathrm{w})$, 1292.2 (w), 1178.4 (s), 1126.3 (w), 1089.7 (w), 1054.9 (w), $1043.4(\mathrm{w}), 1022.2(\mathrm{w}), 1004.8(\mathrm{w}), 943.1(\mathrm{w}), 887.2(\mathrm{w}$, shoulder), $862.1(\mathrm{~m}), 792.6(\mathrm{~m}), 763.7(\mathrm{w}), 742.5(\mathrm{w}), 729.0$ (w), $715.5(\mathrm{~m}), 661.5(\mathrm{~m}), 622.9(\mathrm{~m})$.

FIR (PE pellet): $/\left[\mathrm{cm}^{-1}\right]=562.2(\mathrm{~m}$, shoulder), $509.1(\mathrm{w})$, $498.9(\mathrm{w}), 472.5(\mathrm{w}), 453.2(\mathrm{~m}), 417.5(\mathrm{~m}), 396.3(\mathrm{~m}), 349.1$ (w), $284.5(\mathrm{w}), 230.5(\mathrm{w}), 154.3$ (m, shoulder), $93.5(\mathrm{~s}), 64.6$ (s, shoulder).

Raman: $\quad /\left[\mathrm{cm}^{-1}\right]=3134.2(\mathrm{w}), 3082.9(\mathrm{w}), 2956.7(\mathrm{w})$, 2933.6 (s), 2883.5 (s), 2848.7 (s), 2727.2 (w), 1560.4 (vw), 1452.4 (w, shoulder), $1432.1(\mathrm{w}), 1421.6$ (w, shoulder). 1375.3 (vw), 1334.8 (vw), 1296.2 (w), 1128.4 (w), 1105.3 (vw), 1087.9 (vw), 1062.9 (w), 1014.6 (w), 887.4 (vw), 733.1 (vw), $692.6(\mathrm{vw}), 654.0(\mathrm{vw}), 605.8(\mathrm{vw}), 414.9(\mathrm{vw}), 303.0$ (vw), 231.6 (vw), 181.5 (vw, shoulder), 150.6 (w, shoulder), $114.0(\mathrm{w}), 85.1$ (w, shoulder).

Elemental analysis (\%) calcd for $\left[\mathrm{C}_{12} \mathrm{mim}\right] \mathrm{Br}$ : C 58.00, $\mathrm{H}$ 9.43, N 8.45; found: C 57.63, H 9.74, N 8.42.

$\mathbf{E u B r}_{2}$. According to a literature procedure ${ }^{33} 2.8 \mathrm{~g}(8 \mathrm{mmol})$ europium(III) oxide (99.97\%, Fluka Chemie, Buchs, $\mathrm{CH}$ ) are dissolved in $80 \mathrm{ml}$ conc. $\mathrm{HBr}(48 \%$, Aldrich, Steinheim, D) and $11 \mathrm{~g}(0.112 \mathrm{~mol})$ ammonium bromide $(99.995 \%$, Merck, Darmstadt, D) are added. After all starting materials are dissolved the solvent is boiled off. The residual yellow solid is heated under vacuum at $120^{\circ} \mathrm{C}\left(20^{\circ} \mathrm{C} / \mathrm{h}\right)$ for $6 \mathrm{~h}$, then at $400{ }^{\circ} \mathrm{C}\left(20^{\circ} \mathrm{C} / \mathrm{h}\right)$ for $12 \mathrm{~h}$ before cooling to room temperature $\left(20^{\circ} \mathrm{C} / \mathrm{h}\right)$. The obtained $\mathrm{EuBr}_{2}$ is checked for identity and purity by PXRD (powder X-ray diffraction). 
$\mathbf{L n B r}_{\mathbf{3}}(\mathbf{L n}=\mathbf{S m}, \mathbf{T b}, \mathbf{D y}) . \mathrm{LnBr}_{3}$ was synthesised according to a modified literature procedure. ${ }^{34}$ For $\mathrm{SmBr}_{3}$ and $\mathrm{DyBr}_{3}$ $0.005 \mathrm{~mol}$ of the respective lanthanide(III) oxide $(99.9 \%$ Fluka Chemie AG, Buchs, $\mathrm{CH}$ ) and 0.07 mol ammonium bromide (suprapur ${ }^{\circledR}$ 99.995\% Merck, Darmstadt, D), for $\mathrm{TbBr}_{3} 0.004 \mathrm{~mol} \mathrm{~Tb}_{4} \mathrm{O}_{7}$ (99.9\% Fluka Chemie AG, Buchs, $\mathrm{CH})$ and $0.102 \mathrm{~mol}$ ammonium bromide were dissolved in $48 \%$ conc. aqueous hydrobromic acid (Aldrich, Steinheim, D). After removing the solvent, the formed $\left(\mathrm{NH}_{4}\right)_{3} \mathrm{LnBr}_{6} \cdot \mathrm{yH}_{2} \mathrm{O}$ is decomposed to $\mathrm{LnBr}_{3}$ at elevated temperatures where also any excess of ammonium bromide sublimes of. The crude $\mathrm{LnBr}_{3}$ is then purified by sublimation under vacuum $\left(<10^{-5} \mathrm{mbar}\right)$. The purity of the obtained $\mathrm{LnBr}_{3}$ is checked by PXRD.

$\mathbf{L n X}_{2} / \mathbf{L n X}_{3}$ in $\mathbf{C}_{12}$ mimBr. To obtain lanthanide halide containing $\mathrm{C}_{12}$ mimBr samples the respective amounts of the lanthanide bromide and 1-dodecyl-3-methylimidazolium bromide are heated in a sealed silica ampoule under vacuum at $120^{\circ} \mathrm{C}$ until a homogeneous mixture is obtained. After cooling to room temperature waxy solids are obtained which are subjected to further analysis. Alternatively the lanthanide halide and $\mathrm{C}_{12} \mathrm{mimBr}$ can be dissolved in $\mathrm{CH}_{2} \mathrm{Cl}_{2}$ at room temperature. After removal of the solvent under vacuum, again, waxy samples of the desired composition are obtained.

Instrumentation. Elemental analyses were obtained on an Euro Vektor elemental analyzer EuroEA 3000 (HEKAtech $\mathrm{GmbH}$, Wegberg, D) for $\mathrm{C}_{12} \mathrm{mimBr}$.

${ }^{1} \mathrm{H}-\mathrm{Nuclear}$ magnetic resonance (NMR) spectra were recorded on a Bruker AC-300 spectrometer (operating at 300 $\mathrm{MHz}$ for ${ }^{1} \mathrm{H}$ ) (Bruker Germany GmbH, D).

IR spectra of the solid were recorded using a IFS-66V-S Fourier Transform IR spectrometer (Bruker Optik GmbH, Ettlingen, D); samples were measured pressed in a polyethylene matrix for far IR range $\left(50-600 \mathrm{~cm}^{-1}\right)$ and in a $\mathrm{KBr}$ matrix for middle IR (MIR) range $\left(600-4000 \mathrm{~cm}^{-1}\right)$.

Raman spectra were recorded with a FRA 106-S Fourier Transform Raman spectrometer (Bruker Optik GmbH, Ettlingen, D) at $150 \mathrm{~mW}$. Raman samples were measured in glass capillaries with an inner diameter of $0.1 \mathrm{~cm}$ and 0.15 mm wall thickness.

Differential scanning calorimetry (DSC) was performed with a computer-controlled Phoenix DSC 204 F1 thermal analyser (Netzsch, Selb, D) with argon as protection gas. The samples were placed in aluminium pans which were coldsealed under argon. Experimental data are displayed in such a way that exothermic peaks occur at negative heat flow and endothermic peaks at positive heat flow. Heating and cooling rates were $5^{\circ} \mathrm{C} / \mathrm{min}$. Given temperatures correspond to the onset of the respective thermal process.

Optical polarizing microscopy was carried out with an Axio Imager A1 microscope (Carl Zeiss MicroImaging GmbH, Göttingen, D) equipped with a hot stage THMS600 (Linkam Scientific Instruments Ltd, Surrey, UK) and a temperature controller Linkam TMS 94 (Linkam Scientific Instruments Ltd, Surrey, UK) and crossed polarizers. Images were recorded at a magnification of $100 \times$ as movies with a digital camera after initial heating during the cooling stage. Heating and cooling rates were $5 \mathrm{~K} / \mathrm{min}^{-1}$. For the measurement the samples were placed under argon between two cover slips which were sealed with a two-component adhesive (UHU plus 300, UHU GmbH \& Co. KG, Bühl, D).

UV-Vis spectra were obtained with a Cary 5000 spectrometer (Bruker, Bremen, Germany) at room temperature. Excitation and emission spectra and also luminescence decays were recorded on a Jobin Yvon Horiba Fluorolog FL3-22 (HORIBA Jobin Yvon Inc., Unterhaching, D) with a xenon lamp as the excitation source and a photomultiplier tube for detection. Interconfigurational f-ftransitions are assigned according to the Dieke diagram. ${ }^{35}$

\section{Results and Discussion}

\section{$\mathrm{C}_{12} \mathrm{mimBr}$}

Dry $\mathrm{C}_{12}$ mimBr was chosen as a host matrix with liquid crystalline properties and doped with various amounts of $\mathrm{EuBr}_{2}, \mathrm{SmBr}_{3}, \mathrm{TbBr}_{3}$ and $\mathrm{DyBr}_{3}$.

DSC measurements show that upon cooling liquid samples of $\mathrm{C}_{12} \mathrm{mimBr}$ from the isotropic melt a liquid to liquid crystalline ( $\mathrm{L} \leftrightarrow \mathrm{LC}$ ) phase transition occurs at $99.2^{\circ} \mathrm{C}$ and a liquid crystalline to crystalline phase transition at $14.2^{\circ} \mathrm{C}(\mathrm{LC} \leftrightarrow \mathrm{S})$. Upon heating the samples undergo two solid-solid ( $\mathrm{S} \leftrightarrow \mathrm{SI})$ phase transitions at 2.0 and $7.2^{\circ} \mathrm{C}$ which probably belong to order-disorder transitions of the imidazolium alkyl chains. Then the reversible crystalline solid $\leftrightarrow$ liquid crystalline ( $\mathrm{S} \leftrightarrow \mathrm{LC}$ ) and liquid crystalline $\leftrightarrow$ isotropic liquid ( $\mathrm{LC} \leftrightarrow \mathrm{L}$ ) transitions are observed at $42.0^{\circ} \mathrm{C}$ and $100.2^{\circ} \mathrm{C}$, respectively (Fig. 1).
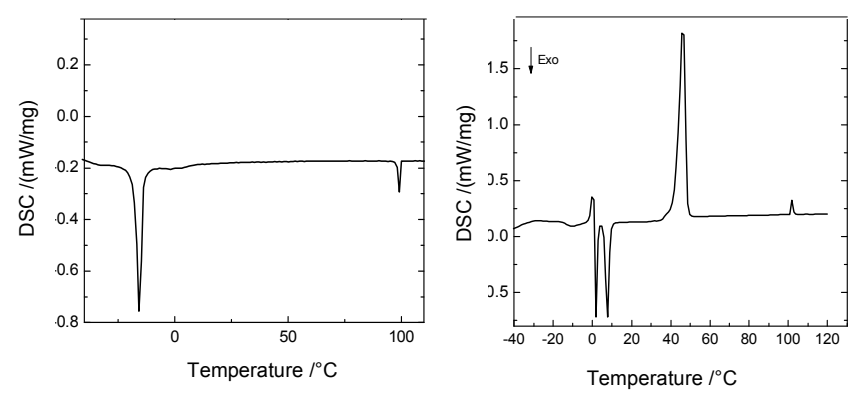

Figure 1. DSC thermograms of neat $\left[\mathrm{C}_{12} \mathrm{mim}\right] \mathrm{Br}$. $1^{\text {st }}$ cooling (left) and $2^{\text {nd }}$ heating (right).

The enantiotropic liquid crystalline mesophase can be identified as a smectic A phase by polarizing optical microscopy (POM). The POM micrographs show focal conic fan textures with dark homeotropic areas. The dark homeotropic areas where no birefringens are observed when the long axis of the imidazolium cations is aligned parallel to the incident polarized light so that the light wavevector can not be rotated. The focal conic fan textures origin when a layered structure forms conical domains. 


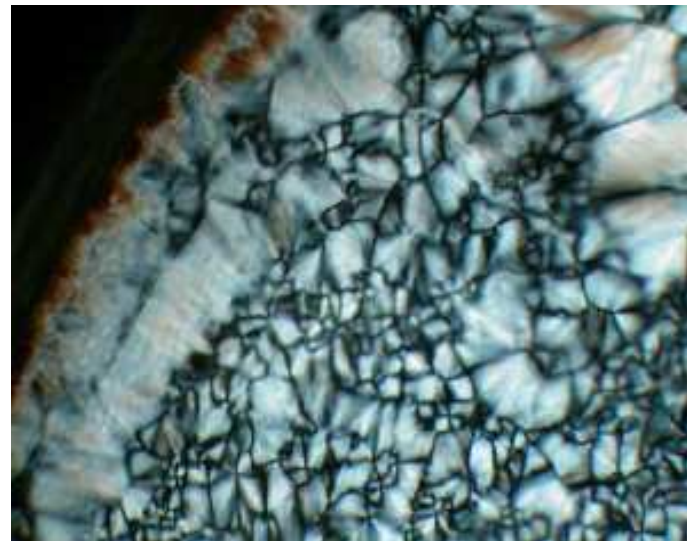

Figure 2. POM micrographs of the $\mathrm{LC}$ state of $\mathrm{C}_{12} \mathrm{mimBr}$.

$\mathrm{C}_{12}$ mimBr alone shows a bluish photoluminescence which is due to electronic transitions within the imidazolium head group. It is well known that the imidazolium $\pi$ electron system can be excited with UV radiation. ${ }^{36}$ The energy of the excited state cannot be easily converted into vibrational energy as mixing between $\pi$ and $\sigma$ orbitals of imidazolium is negligible and, in consequence, photoluminescence can be observed. The photoluminescence of $\mathrm{C}_{12} \mathrm{mimBr}$ at $\lambda(\mathrm{em})=$ $450 \mathrm{~nm}$ after excitation with $\lambda(\mathrm{ex})=366 \mathrm{~nm}$ is due to the allowed $\left({ }^{1} \pi \leftarrow^{1} \pi^{*}\right)$ transition (Fig. 3). The fluorescence decay time is too short to be measured (ns regime). Phosphorescence measurements reveal a second, weaker emission which is detected at $\lambda(\mathrm{em})=515 \mathrm{~nm}$ for the $\mathrm{C}_{12} \mathrm{mim}$ that can be assigned to the spin forbidden $\left({ }^{1} \pi \leftarrow^{3} \pi^{*}\right)$ transition (Fig. 3). Measurements of the luminescence intensity decay reveals a lifetime of $\sim 200 \mu \mathrm{s}$ for the $\left({ }^{1} \pi \leftarrow^{3} \pi^{*}\right)$ transition.

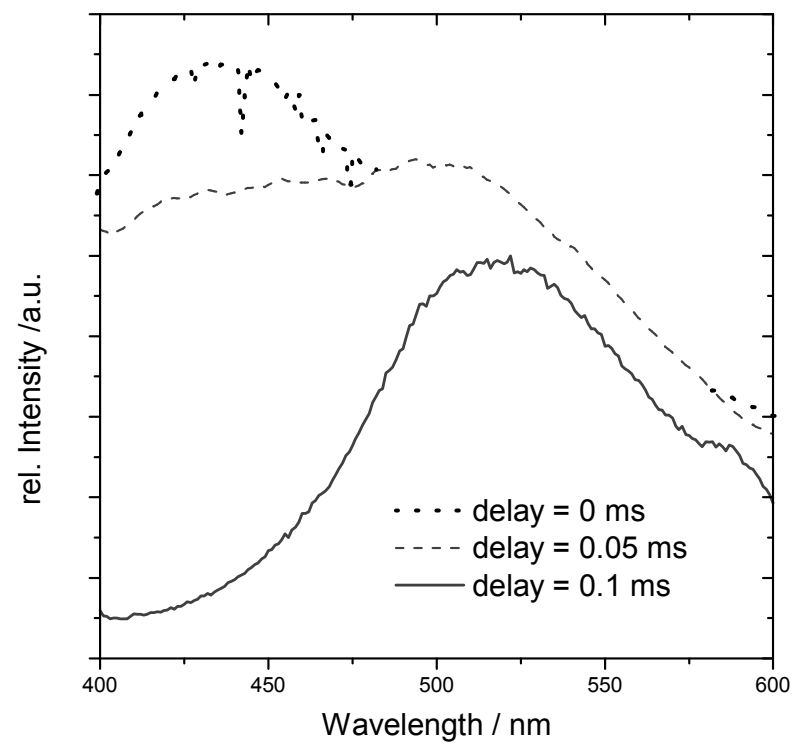

Figure 3. Photoluminescence of $\mathrm{C}_{12} \operatorname{mimBr}$ at $77 \mathrm{~K}, \lambda(\mathrm{ex})=366 \mathrm{~nm}$.

\section{$\mathrm{EuBr}_{2}$ in $\mathrm{C}_{12} \mathrm{mimBr}$}

Figure 4 shows the thermal behaviour of $\mathrm{C}_{12} \mathrm{mimBr}$ doped with different amounts of europium dibromide. All samples show the formation of a liquid crystalline state of matter. By
POM measurements the mesophase can be identified as a smectic A phase (Fig. 5) similar to the mesophase formed by neat $\mathrm{C}_{12} \mathrm{mimBr}$. Samples with 0.5 and $1.0 \mathrm{~mol} \% \mathrm{EuBr}_{2}$ show only small deviations with respect to their thermobehaviour when compared that of neat $\mathrm{C}_{12} \mathrm{mimBr}$. The $\mathrm{S} \leftrightarrow \mathrm{LC}$ transitions are found at $37.6^{\circ} \mathrm{C}\left(0.5 \mathrm{~mol} \% \mathrm{EuBr}_{2}\right)$ and $27.5^{\circ} \mathrm{C}\left(1.0 \mathrm{~mol}^{\%} \mathrm{EuBr}_{2}\right)$ compared to $38.8^{\circ} \mathrm{C}$ for neat $\mathrm{C}_{12} \mathrm{mimBr}$. The $\mathrm{LC} \leftrightarrow \mathrm{L}$ transitions are detected at $98.8^{\circ} \mathrm{C}(0.5$ $\left.\mathrm{mol} \% \mathrm{EuBr}_{2}\right)$ and $101.4^{\circ} \mathrm{C}\left(1.0 \mathrm{~mol}_{0} \mathrm{EuBr}_{2}\right)$ compared to $98.6^{\circ} \mathrm{C}$ for neat $\mathrm{C}_{12} \mathrm{mimBr}$. Larger concentrations of $\mathrm{EuBr}_{2}$ favour the LC state. In samples containing 1.9 and more $\mathrm{mol} \% \mathrm{EuBr}_{2}$ the mesophasic region is extended drastically and the liquid crystalline state is even stable at room temperature and below. The $\mathrm{LC} \leftrightarrow \mathrm{L}$ transitions occur at $0.7^{\circ} \mathrm{C}$ $\left(0.9 \mathrm{~mol} \% \mathrm{EuBr}_{2}\right), 0.5^{\circ} \mathrm{C}\left(2.2 \mathrm{~mol}_{0} \mathrm{EuBr}_{2}\right)$ and $0.3^{\circ} \mathrm{C}(1.0$ $\left.\mathrm{mol} \% \mathrm{EuBr}_{2}\right)$. The clearing points are detected at temperatures similar to that for neat $\mathrm{C}_{12} \operatorname{mimBr}\left(100{ }^{\circ} \mathrm{C}\right.$ for $0.9 \mathrm{~mol}^{\circ} \mathrm{EuBr}_{2}, 99.5^{\circ} \mathrm{C}$ for $2.2 \mathrm{~mol}^{\circ} \mathrm{EuBr}_{2}$ and $100.3^{\circ} \mathrm{C}$ for $2.9 \mathrm{~mol} \% \mathrm{EuBr}_{2}$.

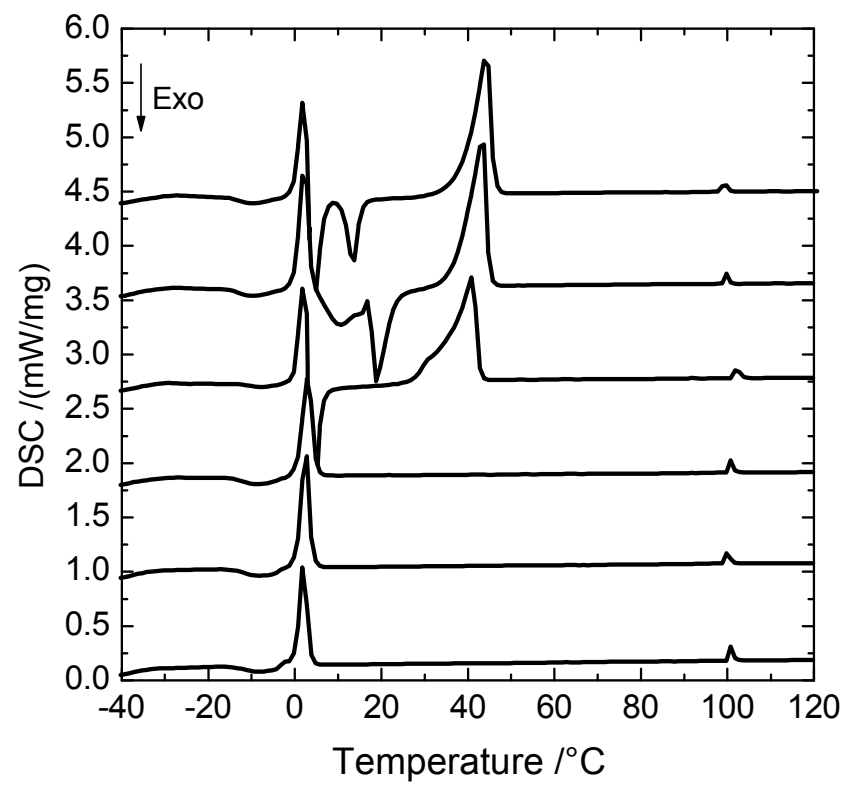

Figure 4. DSC thermograms of $\mathrm{C}_{12} \mathrm{mimBr}$ (top) and $\mathrm{C}_{12} \mathrm{mimBr}$ doped with different $0.5,1.0,1.9,2.2$ and $2.9 \mathrm{~mol}^{2} \mathrm{EuBr}_{2}$ (from top to bottom, $2^{\text {nd }}$ heating cycle).

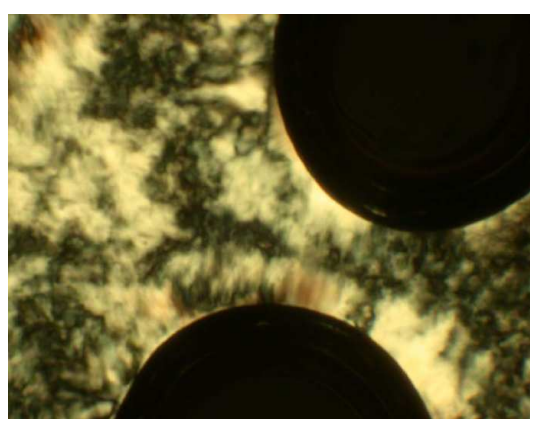

Figure 5. Typical POM micrographs of a $\mathrm{EuBr}_{2}$-doped $\mathrm{C}_{12} \mathrm{mimBr}$ sample in the LC state.

All $\mathrm{EuBr}_{2}$ containing samples show an intense yellow color in agreement with the UV-Vis spectrum where an absorption around $420 \mathrm{~nm}$ can be detected (Fig. 6, left). This absorption 
is due to the $\mathrm{f} \rightarrow \mathrm{d}$-transition of $\mathrm{Eu}^{2+}$ and lies in the expected region.

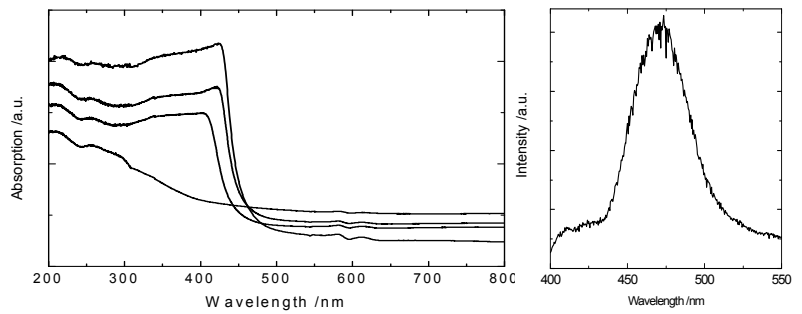

Figure 6. Left: UV-Vis absorption spectrum of $\mathrm{C}_{12} \mathrm{mimBr}$ (bottom) and $\mathrm{C}_{12} \mathrm{mimBr}$ doped with $0.5,1.9$ and $2.9 \mathrm{~mol}^{\circ} \mathrm{EuBr}_{2}$. Right: Photoluminescence spectrum of $\mathrm{C}_{12} \mathrm{mimBr}$ with $2.9 \mathrm{~mol}_{\mathrm{ouBr}} \mathrm{EuBr}_{2}$ (T $=77 \mathrm{~K}, \lambda(\mathrm{ex})=350 \mathrm{~nm})$.

At low temperatures $(77 \mathrm{~K})$ a weak blue emission of $\mathrm{Eu}^{2+}$ can be detected (Fig. 6, right). The emission band shows the typical quite symmetric bell shape expected for $\mathrm{Eu}^{2+}$. The emission maximum upon excitation with $\lambda(\mathrm{ex})=350 \mathrm{~nm}$ is observed at $473 \mathrm{~nm}$. This value lies between that found for $\mathrm{KMgBr}_{3}: \mathrm{Eu}^{2+}(470 \mathrm{~nm})^{37}$ and $\mathrm{CsCdBr}_{3}: \mathrm{Eu}^{2+}(476 \mathrm{~nm})^{38}$.

\section{$\mathrm{SmBr}_{3}$ in $\mathrm{C}_{12} \mathrm{mimBr}$}

Similar to the investigations for $\mathrm{EuBr}_{2} 1.1 \mathrm{~mol} \% \mathrm{SmBr}_{3}$ was doped into $\mathrm{C}_{12} \mathrm{mimBr}$. The thermal behaviour of this sample is similar to that of $\mathrm{C}_{12} \mathrm{mimBr}$ with $1.0 \mathrm{~mol} \% \mathrm{EuBr}_{2}$ (Fig. 7). In this case, the smectic mesophase could be stabilized from about $-9^{\circ} \mathrm{C}$ up to $105^{\circ} \mathrm{C}$.

Low temperature photophysical investigations show aside from transitions in the $\pi$-system of imidazolium the characteristic f- $f$ transitions of $\mathrm{Sm}^{3+}$ at $567 \mathrm{~nm}\left({ }^{4} \mathrm{G}_{5 / 2} \rightarrow{ }^{6} \mathrm{H}_{5 / 2}\right)$, $601 \mathrm{~nm}\left({ }^{4} \mathrm{G}_{5 / 2} \rightarrow{ }^{6} \mathrm{H}_{7 / 2}\right), 648 \mathrm{~nm} \quad\left({ }^{4} \mathrm{G}_{5 / 2} \rightarrow{ }^{6} \mathrm{H}_{9 / 2}\right)$ and $710 \mathrm{~nm}$ $\left({ }^{4} \mathrm{G}_{5 / 2} \rightarrow{ }^{6} \mathrm{H}_{11 / 2}\right)$ (Fig. 8).

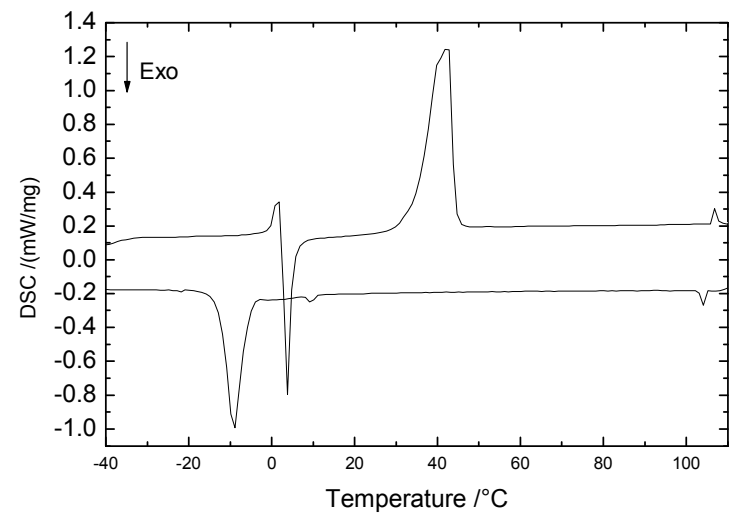

Figure 7. DSC thermogram of $\mathrm{C}_{12} \mathrm{mimBr}$ with $1.1 \mathrm{~mol} \% \mathrm{SmBr}_{3}\left(1^{\text {st }}\right.$ cooling (top) and $2^{\text {nd }}$ heating cycle (bottom)).

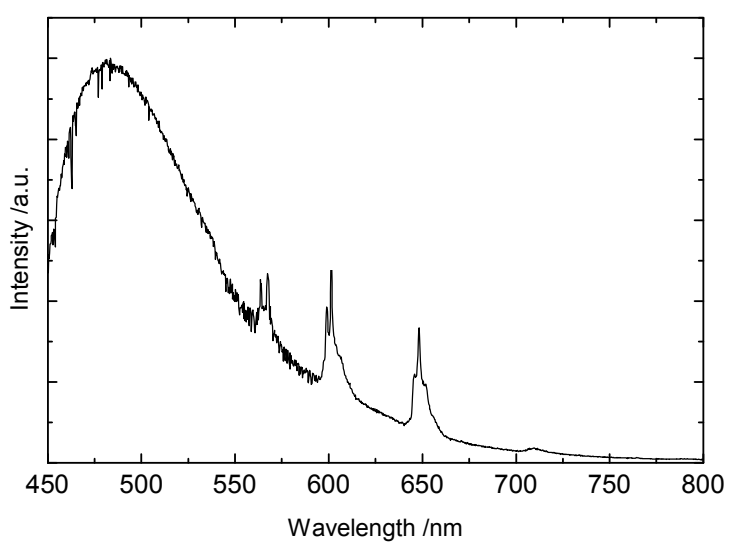

Figure 8. Emission spectrum of $\mathrm{C}_{12} \mathrm{mimBr}$ with $1.1 \mathrm{~mol} \% \mathrm{SmBr}_{3}$ $\left(\lambda_{\mathrm{ex}}=310 \mathrm{~nm}, 77 \mathrm{k}\right)$.

\section{$\mathrm{TbBr}_{3}$ in $\mathrm{C}_{12} \mathrm{mimBr}$}

Doping $\mathrm{C}_{12} \mathrm{mimBr}$ with $1.1 \mathrm{~mol} \% \mathrm{TbBr}_{3}$ yielded a liquid crystalline phase which showed a thermal behavior similar to $\mathrm{C}_{12} \mathrm{mimBr}: \mathrm{Sm}^{3+}$. Upon cooling liquid crystalline mesophase formation is observed from about $100^{\circ} \mathrm{C}$ down to about $10^{\circ} \mathrm{C}$ (Fig. 9). Polarizing optical microscopy suggests that a smectic A phase is formed (Fig. 10).
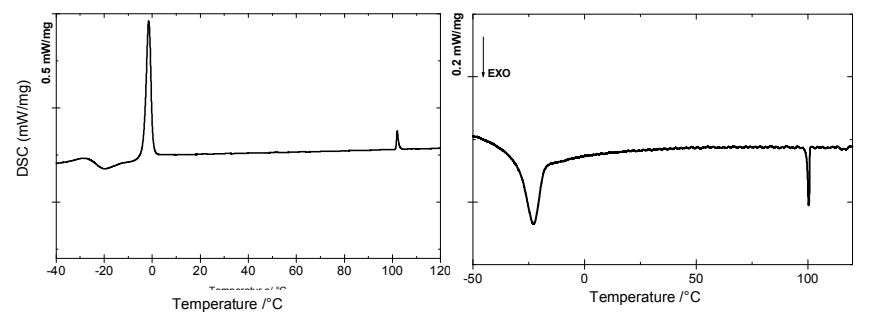

Figure 9. DSC thermogram of $\mathrm{C}_{12} \mathrm{mimBr}$ with $1.0 \mathrm{~mol} \% \mathrm{TbBr}_{3}\left(1^{\text {st }}\right.$ cooling (left) and $2^{\text {nd }}$ heating cycle (right)).

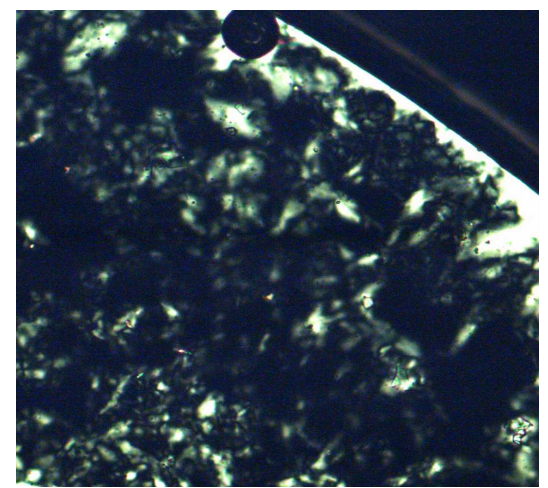

Figure 10. Typical POM micrographs of a $\mathrm{TbBr}_{3}$-doped $\mathrm{C}_{12} \mathrm{mimBr}$ sample in the LC state.

Strong greenish luminescence is observed (Fig. 11). The transitions occur at $488,494 \mathrm{~nm}\left({ }^{5} \mathrm{D}_{4} \rightarrow{ }^{7} \mathrm{~F}_{6}\right), 543,548 \mathrm{~nm}$ 
$\left({ }^{4} \mathrm{D}_{4} \rightarrow{ }^{7} \mathrm{~F}_{5}\right), 583,590 \mathrm{~nm}\left({ }^{4} \mathrm{D}_{4} \rightarrow{ }^{7} \mathrm{~F}_{4}\right), 620 \mathrm{~nm}\left({ }^{4} \mathrm{D}_{4} \rightarrow{ }^{7} \mathrm{~F}_{3}\right)$ and $650 \mathrm{~nm}\left({ }^{4} \mathrm{D}_{4} \rightarrow{ }^{7} \mathrm{~F}_{2}\right)$,

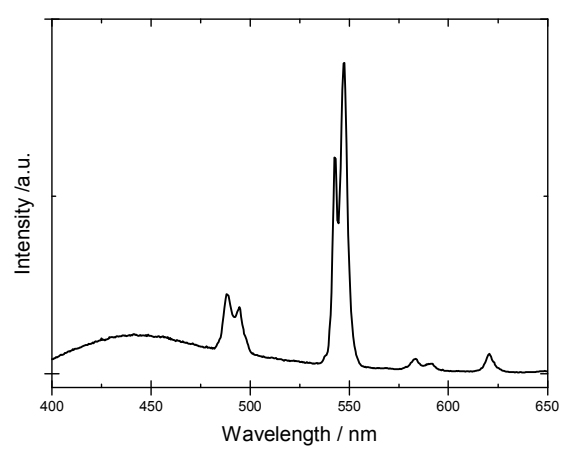

Figure 11. Emission spectrum of $\mathrm{C}_{12} \mathrm{mimBr}$ with $1.1 \mathrm{~mol} \% \mathrm{TbBr}_{3}$ $\left(\lambda_{\mathrm{ex}}=310 \mathrm{~nm}, 77 \mathrm{k}\right)$.

Most interestingly the emission color of the system can be tuned by the choice of the respective excitation wavelength. While excitation with $\lambda_{\mathrm{ex}}=377 \mathrm{~nm}$ leads to the typical yellowish-green emission of $\mathrm{Tb}^{3+}$, excitation with $\lambda_{\text {ex }}$ $=400 \mathrm{~nm}$ yields the typical white emission of $\mathrm{C}_{12} \mathrm{mimBr}$ (Fig. 12 , top and middle). The lifetime of the most intense $\mathrm{f}-\mathrm{f} \mathrm{Tb}^{3+}$ transition is with $\tau=3.4 \mathrm{~ms}$ astonishingly high.

\section{$\mathrm{DyBr}_{3}$ in $\mathrm{C}_{12} \mathrm{mimBr}$}

The system $\mathrm{C}_{12}$ mimBr:Dy ${ }^{3+}$ (9:1) behaves both thermally as well as photophysically similar to the analogous $\mathrm{C}_{12}$ mimBr: $\mathrm{Tb}^{3+}$ system. Again, mesophase formation is observed in the range from $100^{\circ} \mathrm{C}$ down to $\sim-10^{\circ} \mathrm{C}$ (Fig. 12). The textures observed by optical polarizing microscopy point to a smectic mesophase (Fig. 14).

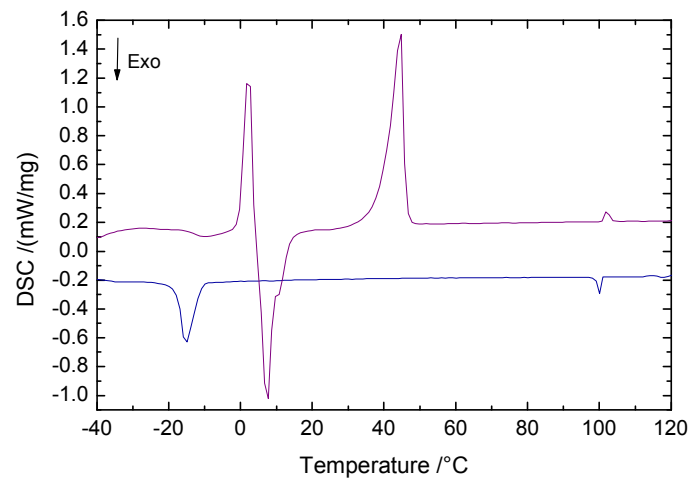

Figure 13. DSC thermogram of $\mathrm{C}_{12} \mathrm{mimBr}: \mathrm{Dy}^{3+}$.

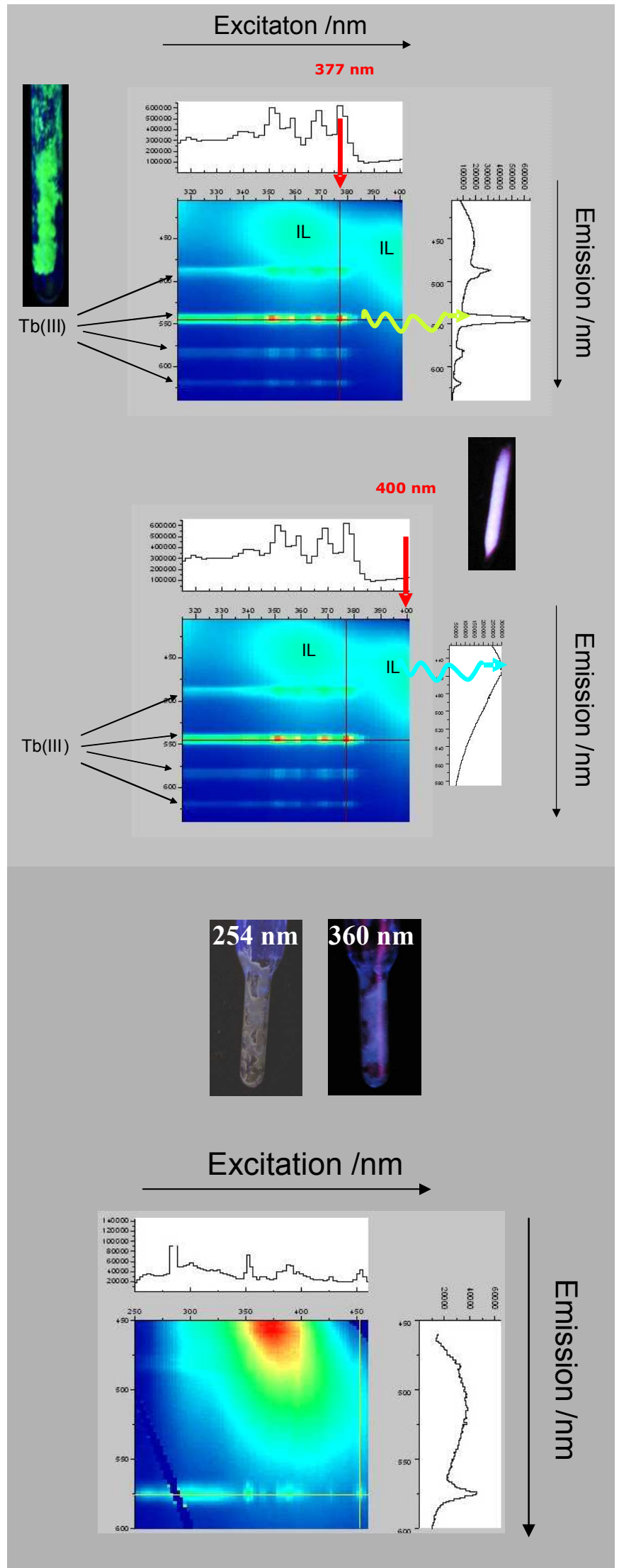

Figure 12. Top and middle: $2 \mathrm{D}$ excitation-emission spectra of $\mathrm{C}_{12}$ mimBr:Tb ${ }^{3+}$; bottom: 2D excitation-emission spectra of $\mathrm{C}_{12}$ mimBr: $\mathrm{Dy}^{3+}$. The photos show the sample under irradiation with short and longer wavelength UV light. 


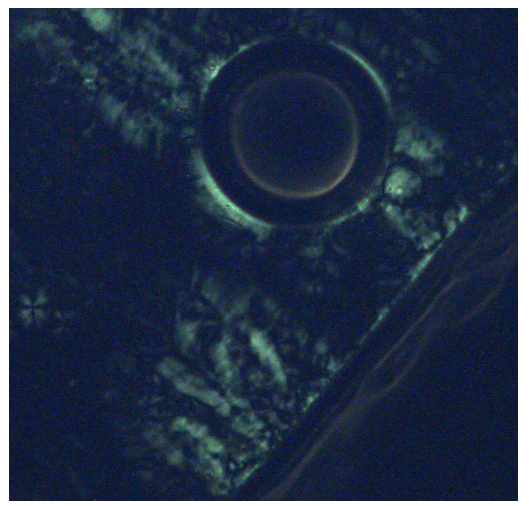

Figure 14. Typical POM micrographs of a $\mathrm{DyBr}_{3}$-doped $\mathrm{C}_{12} \mathrm{mimBr}$ sample in the LC state.

$\mathrm{C}_{12} \mathrm{mimBr}$ doped with $\mathrm{DyBr}_{3}$ shows strong luminescence with transitions at $578 \mathrm{~nm} \quad\left({ }^{4} \mathrm{~F}_{9 / 2} \rightarrow{ }^{6} \mathrm{H}_{13 / 2}\right), \quad 668 \mathrm{~nm}$ $\left({ }^{4} \mathrm{~F}_{9 / 2} \rightarrow{ }^{6} \mathrm{H}_{11 / 2}\right)$ and $754 \mathrm{~nm}\left({ }^{4} \mathrm{~F}_{9 / 2} \rightarrow{ }^{6} \mathrm{~F}_{11 / 2},{ }^{6} \mathrm{H}_{9 / 2}\right)$ (Fig. 15).

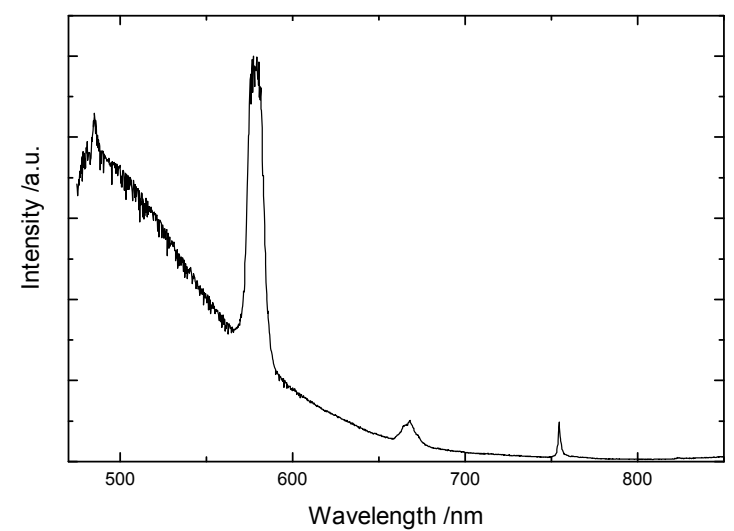

Figure 15. Emission spectrum of $\mathrm{C}_{12} \mathrm{mimBr}$ with $1.1 \mathrm{~mol} \% \mathrm{DyBr}_{3}$ $\left(\lambda_{\mathrm{ex}}=310 \mathrm{~nm}, 77 \mathrm{k}\right)$.

As for $\mathrm{TbBr}_{3}$ in $\mathrm{C}_{12} \mathrm{mimBr}$ the emission color can be tuned by the choice of the respective excitation wavelength. While excitation with the short wavelength $\lambda_{\text {ex }}=254 \mathrm{~nm}$ leads to the characteristic yellowish emission of $\mathrm{Dy}^{3+}$, excitation with $\lambda_{\text {ex }}=360 \mathrm{~nm}$ results in a bluish white emission which originates from the superposition of $\mathrm{Dy}^{3+}$ and $\mathrm{C}_{12} \mathrm{mimBr}$ emissions (Fig. 12, bottom). The lifetime of the most intense $\mathrm{f}-\mathrm{f} \mathrm{Dy}^{3+}$ transition is determined to $\tau=53 \mu \mathrm{s}$.

\section{Conclusions}

$\mathrm{Ln}^{2+}$ and $\mathrm{Ln}^{3+}$ doped $\mathrm{C}_{12}$ mimBr turn out to be promising new soft optical materials. The host material $\mathrm{C}_{12} \mathrm{mimBr}$ itself is an ionic liquid crystal. Lanthanide bromide dopant concentrations of up to $\sim 1 \mathrm{~mol} \%$ seem to have only little effect on the liquid crystalline properties of the host material. All doped materials form layered liquid crystalline mesophases even at room temperature. At the same time all compounds show reasonably good luminescence. Whilst neat $\mathrm{C}_{12} \mathrm{mimBr}$ shows a bluish white emission, by doping
$\mathrm{C}_{12} \mathrm{mimBr}$ with $\mathrm{EuBr}_{2}$ blue luminescence can be achieved. Analogous $\mathrm{Eu}^{3+}$ or $\mathrm{Sm}^{3+}$ materials show a strong red luminescence.

Of special interest is the observation, that the emission color of $\mathrm{C}_{12}$ mimBr doped with $\mathrm{TbBr}_{3}$ and $\mathrm{DyBr}_{3}$ allows for the tuning of the emission color by a mere change of the excitation light wavelength. In case of $\mathrm{TbBr}_{3}$ the color can be changed between green (mainly $\mathrm{Tb}^{3+}$ ) emission and white whereas in case of $\mathrm{DyBr}_{3}$ a switch between organge-yellow and bluish white is possible. It turns out that doping $\mathrm{C}_{12} \mathrm{mimBr}$ with various lanthanide bromides yields interesting new materials which show strong luminescence in the basic colors (Fig. 16) and might be used in active displays in the future.

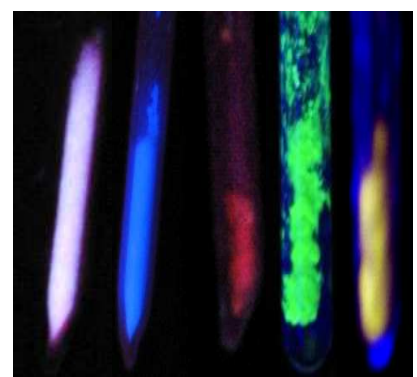

Figure 16. Neat $\mathrm{C}_{12} \mathrm{mimBr}$ (left) doped with various lanthanide bromides under UV-light.

Acknowledgements. This work was supported by the State of Nordrhein-Westfalen, the Universität zu Köln, the RuhrUniversität Bochum as well as by the Deutsche Forschungsgemeinschaft, Bonn.

\section{References}

${ }^{1}$ A. Mele, G. Romano, M. Giannone, E. Ragg, G. Fronza, G. Raos, V. Marcon, Angew. Chem. Int. Ed. 2006, 45, 1123.

${ }^{2}$ P.J. Collings, M. Hird, Introduction to Liquid Crystals: Chemistry and Physics, Taylor \& Francis, 1997.

${ }^{3}$ V.G. Chigrinov, Liquid Crystal Devices, Artech House Optoelectronic Libary, 1999.

${ }^{4}$ C. M. Gordon, J. D. Holbrey, A. R. Kennedy, K. R. Seddon, J. Mater. Chem. 1998, 8, 2627.

${ }^{5}$ E. Alami, H. Levy, R. Zana, P. Weber, A. Skoulios, Liq. Cryst. 1993, 13, 201.

${ }^{6}$ X. Wang, F.W. Heinemann, M. Yang, B. Melcher, M. Fekete, A.-V. Mudring, P. Wasserscheid, K. Meyer, Chem. Commun. 2009, DOI: 10.1039/b914939b.

${ }^{7}$ S. Ujiie, K. Iimura, Macromolecules, 1992, 25, 3174.

${ }^{8}$ For an overview see: K. Binnemans Chem. Rev. 2005, 105 , 4148.

${ }^{9}$ J.L. Serrano, (Ed.), Metallomesogens, Synthesis, Properties and Applications, Wiley-VCH, Weinheim, 1996; F. Neve, F. Adv. Mater. 1996, 8, 277; B. Donnio, D.W. Bruce, 'Metallomesogens' in Liquid Crystals II, edit. by D.M.P. 
Mingos, Springer, Berlin, 1999, 193; R. Giménez, D.P.

Lydon, J.L. Serrano, Current Opinion in Solid State and Materials Science, 2002, 6, 527; I.J.B. Lin, C.S. Vasam, J. Organomet. Chem. 2005, 690, 3498.

${ }^{10}$ F. Neve, Adv. Mat. 1996, 8, 277; I. J. B. Lin, C.S. Vasam, C. S. J. Organomet. Chem. 2005, 690, 3498; N. Hoshino, Coord. Chem. Rev. 1998, 174, 77; P.J. Alonso, Metallomesogens 1996, 387; P.J. Alonso, Metallomesogens 1996, 349; P. Espinet, M.A. Esteruelas, L. A. Oro, J.L. Serrano, E. Sola, Coord. Chem. Rev. 1992, 117, 215. ${ }^{11}$ K. Binnemans, C. Görller-Walrand, C. Chem. Rev. 2002, 102, 2303; C. Piguet, J.C.G. Bünzli, B. Donnio, D. Guillon, D. Chem. Commun. 2006, 3755; E. Terazzi, S. Suarez, S. Torelli, H. Nozary, D. Imbert, O. Mamula, J.-P. Rivera, E. Guillet, J.M. Bénech, G. Bernardinelli, R. Scopelliti, B. Donnio, D. Guillon, J.-C.G. Bünzli, C. Piguet, C. Adv. Funct. Mater. 2006, 16, 157.

${ }^{12}$ V. Salerno, A. Grieco, M.Vacatello, J. Phys. Chem. 1976, $80,2444$.

${ }^{13}$ G.F. Needham, R.D. Willett, H.F. Franzen, H. F. J. Chem. Phys. 1984, 88, 674.

${ }^{14}$ E. Landi, M. Vacatello, M. Thermochimica Acta 1975, 13, 441.

${ }^{15}$ A. Kanazawa, T. Ikeda, Y. Nagase, Y. Chem. Mater. 2000, 12,3776 .

${ }^{16}$ K. Goossens, K.Lava, P. Nockemann, K. Van Hecke, L. Van Meervelt, P. Pattison, K. Binnemans, Th. Cardinaels, Langmuir 2009, 25, 5881; A. Getsis, A.-V. Mudring, $Z$. Anorg. Allg. Chem. 2009, 635, 2214.

${ }^{17}$ C.J. Bowlas, D.W. Bruce, K.R. Seddon, Chem. Commun. 1996, 1625.

${ }^{18}$ F. Neve, A. Crispini, S. Armentano, O. Francescangeli, Chem. Mater. 1998, 10, 1904.

${ }^{19}$ F. Neve, O. Francescangeli, A. Crispini, J. Charmant, J. Chem. Mater. 2001, 13, 2032.

${ }^{20}$ F. Neve, O. Francescangeli, A. Crispini, A. Inorg. Chim. Acta 2002, 338, 51.

${ }^{21}$ F. Neve, M. Impéror-Clerc, Liq. Cryst. 2004, 31, 907.

${ }^{22}$ A. Taubert, Angew. Chem. Int. Ed. 2004, 43, 5380.

${ }^{23}$ C.K. Lee, H.H. Peng, I.J.B. Lin, I. J. B. Chem. Mater. 2004, 16,530

${ }^{24}$ A. Getsis, Dissertation, Universität zu Köln, 2009.

${ }^{25}$ A. Getsis, B. Balke, C. Felser, A.-V. Mudring, Cryst. Growth \& Des. 2009, 9, 4427.

${ }^{26}$ A. Getsis, S. Tang, A.-V. Mudring, Eur. J. Inorg. Chem. 2010 , in press.

${ }^{27}$ M.Grell, D.C. Bradley, Adv. Mat. 1999, 11, 895; M.

O'Neill,; S.M. Kelley, Adv. Mat. 2003, 15, 1135.

${ }^{28}$ L.N. Puntus, K.J. Schenk, J.C.G. Bünzli, Eur. J. Inorg. Chem. 2005, 23, 4739; J. Kocher, F. Gumy, A.-S. Chauvin, J.C.G. Bünzli, J. Mat. Chem. 2007, 17, 654.

${ }^{29}$ Y. G. Galyametdinov, A.A. Knyazev, V.I.Dzhabarov,; T. Cardinaels, K. Driesen, C. Görller-Walrand, K. Binnemans, K. Adv.Mat. 2008, 20, 252; Y.G. Galyametdinov, W. Haase, B. Goderis, D. Moors, K. Driesen, R. Van Deun, K. Binnemans, J. Phys. Chem. B 2007, 111, 13881.

${ }^{30}$ Y. Galyametdinov, M.A.Athanassopoulou, K. Griesar, O. Kharitonova, E.A. Soto Busmante, L. Tinchurina, I.

Ovchinnikov, I.; Haase, W. Chem. Mat. 1996, 8, 922; K.

Binnemans, Y.G. Galyametdinov, R. Van Deun, D.W. Bruce, S.R. Collinson, A.P. Polishchuk, I Bikchantaev, W. Haase,
A.V. Prosvirin, L. Tinchurina, I Litvinov, A. Gubajdullin, A. Rakhmatullin, K. Uytterhoeven, L. Van Meervelt, J. Am. Chem. Soc. 2000, 122, 4335; V.S. Mironov, Y.G.

Galyametdinov, A. Ceulemans, K. Binnemans, K. J. Chem. Phys. 2000, 113, 10293; Y.G. Galyametdinov, W. Haase, L. Malykhina, A. Prosvirin, I. Bikchantaev, A. Rakhmatullin, K. Binnemans, Chem. Eur. J. 2001, 7, 99; Y. Galyametdinov, G. Ivanova, I. Ovchinnikov, A. Prosvirin, D. Guillon, B. Heinrich, D.A. Dunmur, D.W. Bruce, Liq. Cryst. 1996, 20, 831; K. Binnemans, L. Malykhina, V.S. Mironov, W. Haase, K. Driesen, R. Van Deun, L. Fluyt, C. GörllerWalrand, Y.G. Galyametdinov, Y.G. ChemPhysChem. 2001,p 2, 680 .

${ }^{31}$ C. Piguet, J.C.G. Bünzli, B. Donnio, D. Guillon, D. Chem. Commun. 2006, 3755.

${ }^{32}$ A. Getsis, A.-V. Mudring, Cryst. Res. Technol. 2008, 43, 1187.

${ }^{33}$ G. Meyer, S. Dötsch, T. Staffel, J. Less - Common Met. 1987, 127, 155.

${ }^{34}$ G. Meyer, S. Dötsch, T. Staffel, J. Less-Common Met. 1987, 127, 155.

${ }^{35}$ G.H. Dieke, Spectra and energy levels of rare earth ions in crystals, Interscience Publishers, New York, 1968; W.T.

Carnall, H.M. Crosswhite, H. Crosswhite, Energy level structure and transition probabilities in the spectra of trivalent lanthanides in $\mathrm{LaF}_{3}$. Special Report 1977 (Argonne, IL: Chemistry Division, Argonne National Laboratory).

${ }^{36}$ M.D. Lumb, Luminescence spectroscopy, Academic Press, London (1978).

${ }^{37}$ P. P. Larsen, Dissertation, Universität zu Köln, 2004.

${ }^{38}$ F. Pelle, N. Gardant, M. Genotelle, Ph. Goldner, P. Pocher, J. Phys. Chem. Solids 1995, 56, 1003. 